\title{
HUMAN CAPITAL DEVELOPMENT AND CHURCH GROWTH
}

\section{PEACE IBIYEOMIE}

Scholar, Department of Management, Ignatius Ajuru, University of Education, Port Harcourt, River State. Nigeria

\begin{abstract}
The study surveyed human capital development $(\mathrm{HCD})$ and growth of Nigerian churches, as related to training, mentoring and self-development of workers and followers. A survey of 30 randomly selected churches in River state, Nigeria was carried out. The findings revealed that HCD is related to churches growth in Nigeria. The study recommends continuous development of workers and followers to increase performance.

KEYWORDS: Human Capital Development, Training, Mentoring, Self-Learning \& Church Growth
\end{abstract}

Received: Jun 07, 2020; Accepted: Jun 27, 2020; Published: Jul 20, 2020; Paper Id.: IJBMROCT20201

\section{INRODUCTION}

Changes are foreseeable in the organizations, and theneed to be prepared in facing these challenges are essential, as globalisation has improved technology and external environment influences work environment, bringing about new changes in work processes, methods, and procedures and making wise decisions on use and investment in the organisational resources. Quality of life and achievement of goals cannot be improved by investment in equipment, building and properties, without investing in the organisation's greatest resource, the human capital. The organisational resources can only be optimally used when men are strategically developed, placed and used. Thus, it becomes essential for an organisation to improve its workers.

Many followers' skills, knowledge and experience needed to progress ministerial work is low. The church witnessed to people daily; some are ignorant of the word, majority's behaviour and perception to life and words of God is weird, and advancing in ministry is a job for all workers, followers and ministers. An ignorant person cannot impact values and morals in another. It takes knowledge, learning, and skills, to enhance development, stability and progressat work.

Jesus expected the churches to witness and proclaim the gospel, the same way he assembled the community of followers, investing time, energy to train, mentor and empower them. (John 14:12). Many articles and studies have explored human capital development, but the dearth of empirical work on HCD and church growth in Nigeria created a gap in knowledge and a need for this study.

\section{RESEARCH HYPOTHESES}

$\mathrm{Ho}_{1} \quad$ Training does not relate to the growth of Nigerian Churches.

$\mathrm{Ho}_{2} \quad$ Mentoring does not relate to the growth of Nigerian Churches.

$\mathrm{Ho}_{3} \quad$ Self-learning does not relate to the growth of Nigerian Churches. 


\section{LITERATURE REVIEW}

Human capital is the stock of knowledge, social skills, education, individual personal attribute that enhance improved performance and creativity of economic value (OECD,2020). It comprisesthe skills, knowledge, experience, abilities, intelligence, talents, and collective and individual wisdom possessed. Increasing demand for a skilled workforce, and continuous growing labour mobility, requiresthe workers' development.The church cannot develop without skilled human resources to drive its growth.

The innovative and creative products of human minds can only be made productive through effective utilisation of human capital.Investment in human resources can be made through on-the-job training, education, continuous learning and work experience.Armstrong\& Taylor (2017) posits that the constituents of human capital are intellectual capital, organisational capital and social capital. The intellectual capital is the stock and flow of knowledge accessible to a firm. Organisational capital refers to institutionalise knowledge, while social capital is the knowledge derived from networks of relationships. The study examinedHCD from the perspective of training, mentoring and self-development of employees.

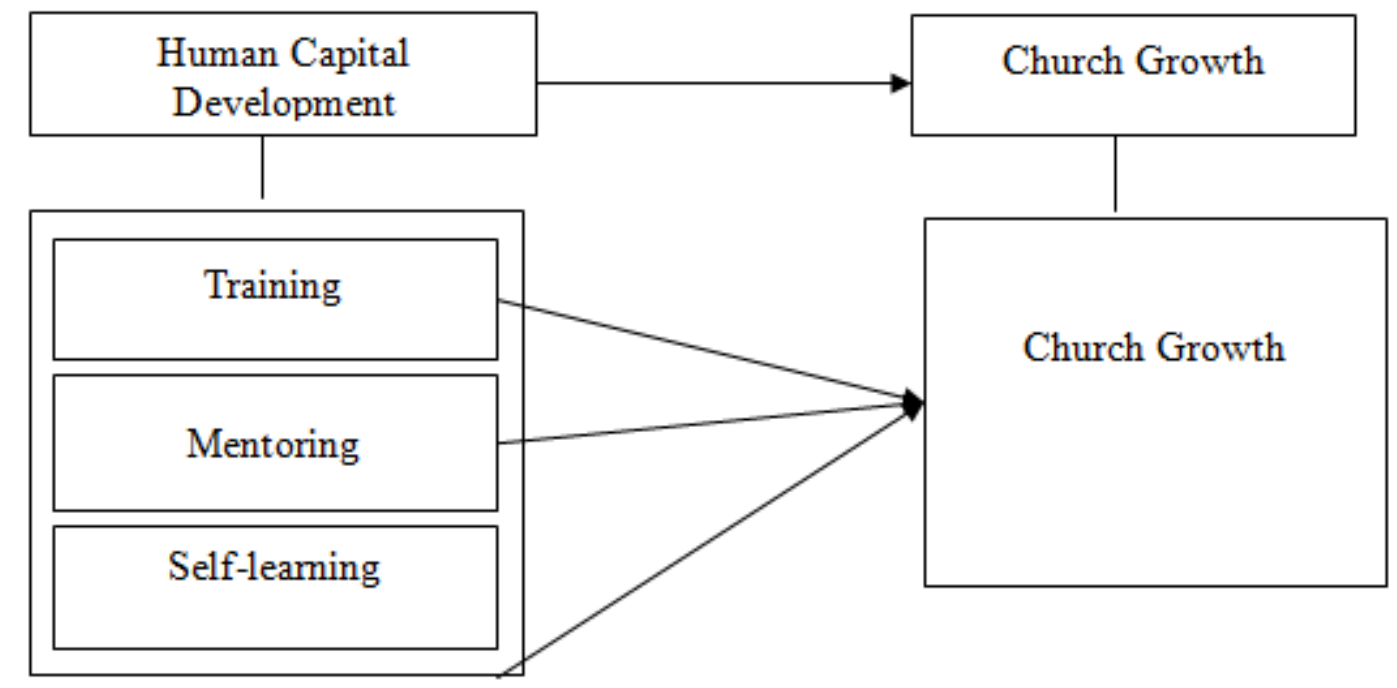

Figure 1: Operational Framework Human Capital Development and Church growth.

Source: Researcher (2020).

Training is teaching and improvement of knowledge, skills, attitudes and abilities needed in an organisation for a specific job. Training is learning skills needed for a job (Cambridge Dictionary, 2020), developing particular skills to a standard (Chand, 2020), use of planned systematic instruction actions to boost learning (Armstrong\& Taylor,2017). Jesus taught, coach, train, empower his followers, given them instructions and inspiring them to share the good news. According to Ibiyeomie (2017), knowledge enhances the ability to reign in any field of life. Job exploit and wisdom was from the knowledge he gained. Improving skills,knowledge and capabilities give the confidence boldness required to have fellowship and witness the word of God.

Training is essential in ministration, witnessing and expansion. Knowledge or skills cannot be satisfactorily acquired by self-learning, experience and experiential learning at the workplace (Armstrong \& Taylor, 2017). Some tasks are complex or difficult and need specialised training from experts and experienced trainers and particular learning need 
peculiar to a group need can be addressed through systematic planned, implemented and evaluated training. Knowledge is crucial in the walk and work of God.Applied knowledge is power.Awise man is strong, but knowledge is the key to his strength (Ibiyeomie, 2017). The knowledge bank for outstanding result in the church is the Bible, which must be studied to show self-approval unto God. The workmen need not be afraid nor ashamed of rightly dividing the word of truth (2Timothy 2:15).

Need for training arises from complexity, environmental changes, task changes, matching specification with job requirement needs andmaintaining good human relations.All methods used for improving the skills, knowledge and abilities of workers shouldgain learners attention,satisfy the learning objectives, provide guidance and feedback.Training can be carried out through internal or external sources and e-learning, in the form of induction training, job instruction training, refresher training, apprenticeship and vestibule training. Training can be on-the-job or off-the-job training. Examples of on-the-job training arecoaching, job rotation, instructions, assignments and internship training while off-thejobs are role-playing, case study, grid training, lectures, business games, basket method, conferences, simulation and management education.

Mentoring is using trained individuals, known as mentors to provide guidance, realistic advice and care that helps the mentee to develop and learn.More experienced, knowledgeable, and connected (mentor), passes knowledge, skills and acquired abilities to a mentee within a certain field (Oshinkale, 2019).A mentor advises, give information's on corporate culture, guidance, directions and give listening ear by acting as a parental figure (Armstrong \& Taylor, 2017); and givinga wider career and individual developments.Mentor nurture, teach, encourage, respect, manage the relationship and respond to learnersby usingunique roles that meet learner's requirement, such as acting as a coach, a role model, counselor, friend, and adviser. In the church, a mentor is expected to guide the less experienced workers and followers, build trust,confidence, model positive behaviours, impact knowledge, meet learners' needs and career development.

Self-learning is an opportunity forachieving life aspirations to be focused, and relevant in a changing world, by making deliberate efforts to identify the problem and proffer solution through internet, exploration and learning from people's contributions. Self-learning is using initiatives to recognise needs, goals and assessing thelearning outcomes(Knowles in Reader, 2018).Self-learning enhances more understanding and steadfastness. Providing the tools needed for gaining knowledge enhances the individual search for learning.

Self-learning involves being curious, setting goals, assessing learning resources (Ho, 2020), learning engagement, application, collaboration and sharing of knowledge.At a young age, Jesus studied in the synagogue (Luke 4; 16; Luke 2: 46-47), he seeks for knowledge and people were amazed at His wisdom. Just as Christ is knowledgeable, he expects his follower to develop their abilities and consciously seek for knowledge. Therefore, to continually grow, the potentials and competency of workers and followers should be developed.

\section{METHODOLOGY}

The study was carried out as a survey with 30randomly selected churchesin Port Harcourt, Nigeria. The unit of analysis is micro. The population is 500 workers of the selected sample. Using Krejcie and Morgan' 1970 table, the sample size was fixed at 217 workers. Two hundred and seventeen questionnaires (217) were administered, but only two hundred (200) was returned and used in the analyses. The instrument, a questionnaire was rated on a 4-point Likert scale.The instrument items were collated and analysed with Spearman Rank Correlation coefficient at 0.05 level of significance. 


\section{RESULTS AND DISCUSSIONS}

Spearman rank correlation was used to test the correlation and strength of the relationship, and the decision rule is to reject the null hypotheses, where $\mathrm{p}<0.05$ significant level and accept the null hypotheses, where $\mathrm{p}>0.05$.

\section{Ho $\quad$ Training does not Relate with Church Growth}

Table 1: Training and Church Growth

\begin{tabular}{|c|c|c|c|c|}
\hline \multicolumn{5}{|c|}{ Correlations } \\
\hline & & & Training & Church Growth \\
\hline \multirow{6}{*}{ 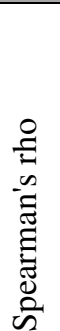 } & \multirow{3}{*}{ Training } & $\begin{array}{l}\text { Correlation } \\
\text { Coefficient }\end{array}$ & 1.000 & $.625^{* * *}$ \\
\hline & & Sig. (2-tailed) & & .000 \\
\hline & & $\mathrm{N}$ & 200 & 200 \\
\hline & \multirow{3}{*}{$\begin{array}{l}\text { Church } \\
\text { Growth }\end{array}$} & $\begin{array}{l}\text { Correlation } \\
\text { Coefficient }\end{array}$ & $625^{* * *}$ & 1.000 \\
\hline & & Sig. (2-tailed) & .000 & \\
\hline & & $\mathrm{N}$ & 200 & 200 \\
\hline
\end{tabular}

Source: SPSS Output, (2020)

Table 1 shows theresults of analyses on training and church growth. The result of the data analysis reveals a positive significant level $p<0.05(0.000<0.05)$, rho is. $625^{* *}$, thisreveals the existence of a relationship betweentraining and church growth. The null hypothesis is rejected, upholding that training has a significant relationship with church growth.

\section{$\mathrm{Ho}_{2} \quad$ Mentoring does not Relate with Church Growth}

Table 2: Mentoring and Church Growth

\begin{tabular}{|c|c|c|c|c|}
\hline \multicolumn{5}{|c|}{ Correlations } \\
\hline & & & Mentoring & Church Growth \\
\hline \multirow{6}{*}{ 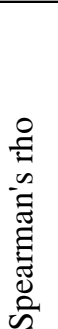 } & \multirow{3}{*}{ Mentoring } & $\begin{array}{l}\text { Correlation } \\
\text { Coefficient }\end{array}$ & 1.000 & $.575^{* *}$ \\
\hline & & Sig. (2-tailed) & & .000 \\
\hline & & $\mathrm{N}$ & 200 & 200 \\
\hline & \multirow{3}{*}{ Church Growth } & $\begin{array}{l}\text { Correlation } \\
\text { Coefficient }\end{array}$ & $575^{* *}$ & 1.000 \\
\hline & & Sig. (2-tailed) & .000 & \\
\hline & & $\mathrm{N}$ & 200 & 200 \\
\hline
\end{tabular}

Source: SPSS Output, (2020)

The results in Table 2 shows a p-value less than $0.05(0.000<0.05)$. The rho $=0.575^{* *}$. This reveals a positive correlation between mentoring and church growth. The null hypothesis is rejected, upholding that mentoring has a significant relationship with church growth.

\section{$\mathrm{Ho}_{3}$ Self-learning does not Relate with Church Growth}

Table 3: Self-learning and Church Growth

\begin{tabular}{|c|c|c|c|c|}
\hline \multicolumn{5}{|c|}{ Correlations } \\
\hline & & & Self-learning & Church Growth \\
\hline \multirow{4}{*}{ 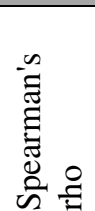 } & \multirow{3}{*}{ Self-learning } & $\begin{array}{l}\text { Correlation } \\
\text { Coefficient }\end{array}$ & 1.000 & $.655^{* * *}$ \\
\hline & & Sig. (2-tailed) & & .000 \\
\hline & & $\mathrm{N}$ & 200 & 200 \\
\hline & & Correlation & $655^{* *}$ & 1.000 \\
\hline
\end{tabular}




\begin{tabular}{|l|l|l|l|l|}
\hline \multirow{3}{*}{$\begin{array}{l}\text { Church } \\
\text { Growth }\end{array}$} & Coefficient & & \\
\cline { 3 - 5 } & Sig. (2-tailed) & .000 & \\
\cline { 2 - 4 } & $\mathrm{N}$ & 200 & 200 \\
\hline
\end{tabular}

Source: SPSs Output, (2020)

The result in table 3 reveals a significant level $p<0.05(0.000<0.05)$, rho $=.655^{*}$. This means that Self-learning correlates church growth. The null hypothesis, $\mathrm{Ho}_{3}$, is rejected, and the alternate retained.

\section{Table 4: Summary of Test Hypotheses}

\begin{tabular}{|l|l|l|}
\hline \multicolumn{1}{|c|}{ Hypotheses } & Significance & Decision \\
\hline Ho1: Training does not relate with church growth & Significant & Reject \\
\hline $\begin{array}{l}\text { Ho2: Mentoring does not relate with church } \\
\text { growth. }\end{array}$ & Significant & Reject \\
\hline $\begin{array}{l}\text { Ho3: Self-learning does not relate with church } \\
\text { growth. }\end{array}$ & Significant & Reject \\
\hline
\end{tabular}

\section{CONCLUSIONS}

The study examines Human capital Development and church growth in some selected churches in Rivers State. The dimensions of human capital development in this study are training, mentoring and self-learning. The analyses revealed a relationship between human capital development (HCD) and church growth. All the null hypothesesshown in table 4 were rejected, and the alternate accepted, indicating the importance of investing in human resources; as developing the human capital enhances the organisational goals.

\section{RECOMMENDATIONS}

- The management should develop the knowledge and skills of their workforce through efficient training to improve competitiveness and productivity

- $\quad$ Self-learning should be encouraged for innovative and creative ideas

- The workers should be mentored for effective performance

- Employee development programs should be carried outcontinuously

- The church should invest in their human capital to generate valuable returns

\section{REFERENCES}

1. Armstrong, M., \& Taylor, S. (2017). Armstrong's handbook of human resource management practice (Fourteenth). London: KoganPage. 365-366, 660 .

2. Cambridge Dictionary (2020). Training. Dictionary. Cambridge,

3. https://dictionary.cambridge.org/dictionary/english/training. Assessed13/6/2020.

4. Chand, S. (2020). Training: Meaning, Definition and Types of Training. Your Article Library, https://www.yourarticlelibrary.com/human-resource-development/training-meaning-definition-and-types-of-training/32374. Assessed on 13/6/2020.

5. Ihuah, PAULINUS WOKA, C. H. U. K. W. U. E. M. E. K. A. Ekenta, and B. A. R. T. H. O. L. O. M. E. W. Nwokorie. "Impacts of inadequate infrastructures provision on real property value: a comparative study of Agbama and Ehimiri housing estate, Umuahia, Nigeria." International Journal of Environment, Ecology, Family and Urban Studies 4.4 (2014): 9-20. 
6. HO, L. (2020). 7 Steps to make self-learning effective for you. Lifehack.Org

7. https://www.lifehack.org/853724/self-learning. Assessed on 14/6/2020.

8. HERMIT, JYOTI TABITA. "ENVIRONMENTAL STEWARDSHIP: EMERGING TRENDS IN CHRISTIAN ECOLOGICAL ETHICS. "International Journal of English and Literature (IJEL) 5.1, Feb 2015, 97-104

9. OECD (2020). Productivity, human capital and educational policies. OECD.Org.

10. http://www.oecd.org/economy/human-capitall. Assessed on 14/6/2020.

11. ABUBAKAR, BASHIR. "ASSESSMENT OF LAND USE/LAND COVER CHANGES IN THE UPPER BENUE REGION ADAMAWA STATE, NIGERIA."International Journal of Environment, Ecology, Family and Urban Studies (IJEEFUS) 4. 2, Apr 2014, 1-8

12. Oshinkale, Y. (2019). Definition of mentorship: What is a mentor and do you need one?World Education Services, https://www.wes.org/advisor-blog/definition-of-mentorship/. Assessed on 13/6/2020.

13. Reader, S. (2018). Self-Learning; Why it's essential for you in the 21st century.Medium.Com, https://medium.com/wondrblog/self-learning-why-its-essential-for-us-in-the-21st-century-9e9729abc4b8. Assessed on 13/6/2020.

14. Wikipedia (2020) Human capital development. Wikipedia.Org,

15. https://en.wikipedia.org/wiki/Human_capital. Assessed on 14/6/2020. 